This is a self-archived version of an original article. This version may differ from the original in pagination and typographic details.

Author(s): Kuuva, Sari; Heimonen, Kirsi

Title: A Corridor That Moves : Corporeal Encounters with Materiality in a Mental Hospital

Year: 2020

Version: Published version

Copyright: (c) 2020 Transcript Verlag

Rights: $C C$ BY-NC 4.0

Rights url: https://creativecommons.org/licenses/by-nc/4.0/

Please cite the original version:

Kuuva, S., \& Heimonen, K. (2020). A Corridor That Moves : Corporeal Encounters with Materiality in a Mental Hospital. In M. Ankele, \& B. Majerus (Eds.), Material Cultures of Psychiatry (pp. 334-353). Transcript Verlag. https://doi.org/10.14361/9783839447888-021 


\section{A Corridor That Moves: \\ Corporeal Encounters with Materiality in a Mental Hospital}

Kirsi Heimonen and Sari Kuuva

Prologue

A corridor, the narrow area that leads to or from somewhere, a passageway that is situated in between exits or entrances and that connects rooms, is often a waiting room for appointments, such as for a doctor. It leads to the main space and what that space offers or requires. It can also become a meeting place, a space in which to encounter something new, as its in-betweenness suggests. In addition, a corridor has a unique character of its own.

In our research data, Finnish writers describe their memories of different mental hospitals in Finland from the I930s until the 20IOs. In the mental hospital context, the corridor creates the first impression of the institution: anxiety, uncertainty, or relief are all experienced by patients by walking through it. When one is not allowed to leave, walking or strolling indoors is only possible in the hospital corridors. When one is taken to isolation rooms or treatments via corridors, one has time to prepare oneself - to become more terrified or calmer or to experience any of the feelings in between.

The sound of steps in a corridor informs the hearer about the person in it, about the speed of gait, the material the walker's shoes are made of, and the way in which the walker places each foot on the floor. The form and spatiality of a corridor triggers memories of running, e.g. oneself as a child, through corridors elsewhere.

People move along, pause and wait in corridors. Everything moves, including the corridor, since it contracts in length, even if only very slowly. The notion of change, how people, materialities, and objects are constantly in motion, makes research and writing about this topic challenging. However, the impermanent nature of movement and what can be shared and conveyed through art can be viewed as an opportunity. 
We, an artist-researcher and a researcher on visual art and culture, have produced, in both art and academic contexts, performative events of memories for various audiences. These events have entailed movement, reading written memories aloud, and exhibiting historical and contemporary photographs of exteriors and interiors of mental hospitals. In this article, we discuss the kind of insights and knowledge that emerge when written memories about materialities and material objects are read aloud and accompanied with movement and photographs of mental hospitals. ${ }^{1}$

Like a corridor, this article leads to the threshold of something, while not fully illuminating the rooms that lead off it. However, combining writing with a collaborative research method that focuses on movement and photographs in attuning to memories and their material-affective nature and to the meaning of the materiality of lived experiences of a mental hospital can have a powerful impact. The corridor as a passageway holds generative power - even comparable to a birth canal - and underscores in this article the power of art and alternative research methods.

Interestingly, a kind of "corridor theory," referring to a space of transition, i.e. a philosophical orientation toward experience as the experimental process of becoming, can be found in pragmatism (Bordogna cited by McCormack 20I3: 3I). However, in this approach, including when we are thinking of a corridor as a metaphor for shedding light on this method and the processes it entails, we are not dealing in metaphor alone, since corridors as architectural spaces form the site of the experiences of mental hospital patients and visitors. The feel of the walls and floor of a corridor, the lived experience of its materiality when moving or walking along it, is embedded in the present research method. Corporeal encounters in, at, or along a corridor are crucial, since the human being is entangled, intertwined or inter-enmeshed in more than just the human world - in the present context also with materiality and material objects.

Among other materialities and immaterialities, the corridor becomes one of the things we attach to, a meeting place of memories, physical corridors, photographs, movement, and thoughts. In other words, we are interested here in the material and corporeal dimensions of memories, and how the qualities of memories can be conveyed and shared with an audience in a performative event combining movement, spoken text, and photographs. We unfold our method of performing memories and discuss the material-corporeal dimensions of people's memories of mental hospitals. We focus, in particular, on memories where the relation between the individual and the physical environment of the mental hospital is described and the attention is drawn to the materiality of objects. 
The written memories collected from the present sample of mental hospital patients and visitors are lived, embodied ones, and their transformation into movement, paying attention to the materiality around them, may resonate with an audience even though the knowledge embedded in them is mostly inexpressible. The selection of the memories took place in corporeal reading by Kirsi in which she allowed the material to resonate in her corporeality. In a way, the chosen material haunted her in order to be chosen for further exploration. That act of selection can also be called intuition. The excerpts that drew her attention all have a common feature: the relation with humans and the materiality in mental hospitals.

We cast light on these issues - illuminate the corridor - by beginning with a description of the research material and theoretical background along with thoughts that extend beyond our collaborative research method. We then present three excerpts from written memories, together with photographs, and our independent readings of them. At places, the writing may seem uneven or patchy, since as different researchers our sentences are interwoven from differing perspectives. However, this collaborative effort may result in a kind of synthesis that foregrounds the various possibilities generated by encounters with materiality. The conclusion presents the insights and interpretations gained through this method and discusses ethical questions relating to memories of mental hospitals. Thus, the article contains both an introduction to the method and corporeally oriented interpretations of past experiences.

\section{Researching through Materiality}

Our research data, people's memories and experiences of Finnish mental hospitals, were collected in 2014 and 2015 in collaboration with the archive of the Finnish Literature Association (SKS). The memories comprise about 500 pages of text written by 90 persons - patients, friends, and relatives of patients, and hospital staff and their children. The oldest memory dates from the I930s and the most recent ones date from the 2oros. In our multidisciplinary research project Engraved in the Body: Ways of reading Finnish people's memories from mental hospitals, five researchers are investigating the historical, cultural, bodily, spatial, and affective aspects of memories. $^{2}$ 
We approach the materiality of mental hospitals through the (post)phenomenologically oriented literature, applying this approach to its entanglement with humans and non-humans and the (metaphorical) notion of vital materiality that informs, e.g., the texts of Jane Bennett (2010) and Sara Ahmed (2010). Our primary focus is on interaction and the quality of encounters between human beings and material objects. Here the thoughts of Bruno Latour (2005) on objects as agents come into play.

Furthermore, we discuss the notion of corporeal empathy in the context of human beings and their encounters with materiality in mental hospitals. In this study, corporeal empathy is understood as a method of attunement: the mover attunes to the lived memories that trigger the movement while simultaneously the members of the audience attune to the corporeality of the mover, a process which may lead them to resonate with a particular kind of corporeal experience. Our notions of corporeal empathy draw on the phenomenologically oriented writings of Edith Stein (1989 [1916]). ${ }^{3}$

The experience of others is always encountered through one's own corporeality. One's present corporeal state, past experiences, and imaginative ability are interwoven with the experiences of others. Empathy refers not just to movements of the mind but also to movements of the body, the senses and the ways of interacting with other bodies and material objects (cf. Aaltola/Keto 2017: 60-95). Empathy can be understood as a specific act whereby a person focuses on another's experience and empathises with it, but simultaneously distinguishes between the other's experience and her/his own empathic experience. The person who empathises knows that she/he cannot experience the primordial experience (Stein I989 [19I6]: IO; cf. Parviainen 2003: 328).

Corporeal empathy pierces the different phases of research: reading the written material, selecting excerpts, choosing photographs, reading the excerpts aloud, and fleshing them out through movement. The writers' memories support this reading. Their descriptions involve materialities and immaterialities in a mental hospital and reveal the ways they have attached themselves to material objects. Our aim is to create conditions for the awakening of corporeal empathy for the audience through performative events.

We consider corporeal empathy to be a thus far uncharted possibility in approaching experiences related to mental hospitals. Corporeal empathy can take various directions: listening to others' memories, looking at photographs, and through watching or performing movement. Intersubjectivity, which is an important incor- 
Heimonen/Kuuva

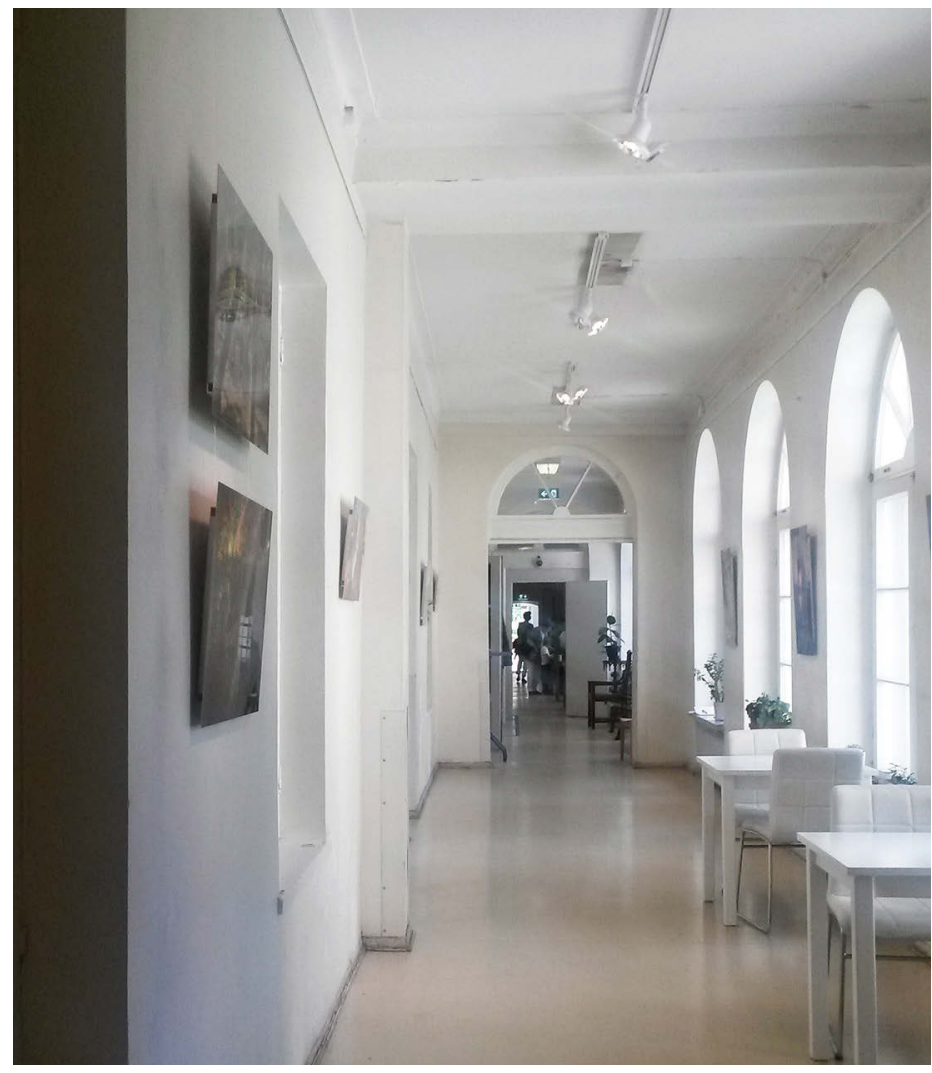

Fig. 1: Corridor in Lapinlahti hospital,

(C) Sari Kuuva, 2017 
poreal interpretation of memories, reaches all the senses and the inter-materiality described in memories as well as the immaterialities present at the site of the performative events. Thus, corporeal empathy is a central notion in our collaborative method designed to awaken imagination and compassion, remind us of our own corporeality, and access corporeal dimensions experienced in the past. In addition to words, pictures, and movement, the material environment activates empathy when the attention is guided to it by the performative event.

\section{Corridor, Room, and Window Sill}

For this article, we approached the materiality of mental hospitals by selecting three extracts from the written memories. In the following we offer two different approaches to each of them, a kind of dialogue of two monologues. Apart from corridors, the research material contains numerous descriptions of patients' rooms and window sills.

Kirsi:

My background is in dance and somatic practices. One specific somatic method, the Skinner Releasing Technique (SRT), has a strong influence on my life: moving, thinking, writing, breathing. The principles of this technique, ${ }^{4}$ e.g. letting go, maintaining a watchful state, effortless effort, and suppleness, are embedded in the corporeality resonating in my encounters with materiality. Furthermore, cultivation of the transparency of the self enhances one's possibilities to perceive the unperceivable in material encounters - here in perceiving memories.

While each excerpt contains an abundance of impulses for me as the performer to follow, the selection process is almost untraceable during the performance. The sound of the words awakens something that resonates in each performative venue. The materiality of the site, the texture of the floor under my feet, the color of the walls, or the posture of a spectator will have some influence on the event. In each venue, encounters with materialities occur through movement and this resonating corporeality. The practice of the Skinner Releasing Technique has brought forth crucial features of the event: attuning and surrendering to each moment, the mover has become merely a vehicle in the happening, in which the temporal absence of the known I and the lessened control over mover's actions emerge. 
The availability of memories and openness to both them and the present situation can thus be described through the resonance that is vital in the creation of a movement and in the happening overall. Jean-Luc Nancy describes how a person "is perhaps no subject at all, except as the place of resonance, of its infinite tension and rebound, the amplitude of sonorous deployment and the slightness of its simultaneous redeployment" (2007: 22). Nancy is referring mainly to the auditory sense; here, however, the core of the resonance lies in listening in and through one's corporeality, a kind of vibration that is lived, and how the whole situation affects it. In the act of moving, listening through one's corporeality refers not only to hearing, since all the senses are acting mutually, but to being attentive to the ingredients of the situation through which movement and speech come into being.

\title{
Corridor
}

\author{
In some wards, I paid attention to the wide corridors that gave rise to \\ a feeling of space when walking through them ... and that brought \\ imagination into play. ${ }^{5}$ (SKS 0395 Patient)
}

Sari:

As a researcher of visual art and culture, I have primarily focused on the relationship between visuality and emotionality in people's memories of mental hospitals. For our performative events I have tried to find photographs that somehow resonate with the selected extracts from written memories. Here, resonance refers to an aspect shared by picture and text, although they are not similar. I suppose that the juxtaposition of texts and photographs can create a tension similar to that induced by the juxtaposition of words and movements. In both cases, the goal is to activate spectators' corporeal memories by creating tensions through the deployment of different media and the stimulation of various modalities. As a background to our performative events we used both historical and contemporary photographs of the exteriors and interiors of Finnish mental hospitals.

In discussing the ability of things to "authorize, allow, afford, encourage, permit, suggest, influence, block, render possible, forbid" human action, Bruno Latour refers 
to the notion of affordance introduced by James Gibson (Latour 2005: 72). According to Gibson, affordance of the environment offers the animal what it provides or furnishes (Gibson 1979: 127). In the hospital environment, material objects or things like corridors and window sills are affordances for walking, running, jumping, sitting, or even dancing - depending on the person who is experiencing the space in a particular situation. As Theodor Lipps, the German philosopher and early theorist of empathy, suggested, we can mentally imitate the rhythm or compositional dynamism of the space and experience this dynamism as emotion (Lipps I960 [1903]:38I-382).

Henri Bergson was interested in the durational dimension of the human experience and drew attention to the mind's capacity to attribute meaning to each present instant through recourse to past corporeal memories (Jones 20I2: I2-13). By means of photographs, both temporal changes and spatial differences between hospitals become visible. The traces of time can be seen in the abrasion of surfaces. For example, traces of the footsteps of previous inmates or staff can sometimes be perceived in the corridors and staircases of old hospital buildings. In her study of the materiality of district psychiatrist centers, Inger Beate Larsen (2008) cites a patient who experiences the old hospital building as soulful. ${ }^{6}$ When buildings are renovated, the traces of the past may disappear.

Kirsi:

Attuning to memories of the site in its materiality and listening to these memories through corporeality extends to photographs as they guide the dancer's way of moving, acknowledging dancing as a thoughtful act (yet one that is not wholly consciously controlled). I discuss the chosen excerpts through the thoughts corporeally aroused in moving, and they are linked with the observations of the photographs.

A corridor as a space to pass through, to run along like a child all the way up to the wall at the other end. Even if the corridor is a narrow space such as that between the rows of chairs at the performance site, or even if it is only a short distance, the words read aloud trigger a change in the rhythm of movement. To feel the air flowing along my ribcage and sides while running, while the speed of movement creates ripples of air that can be felt on the skin by people sitting close by. Perhaps this rush of air brings memories closer, reminding those present of the corporeality beyond them, a token of the aliveness of memories. The image of the airiness of the corridor and its form gives an impression of inter-spatiality hinting at a state of being in-between, between patient's rooms, offices, the kitchen, and treatment rooms, between various historical events, of dwelling in the midst of materialities, and being affected by 

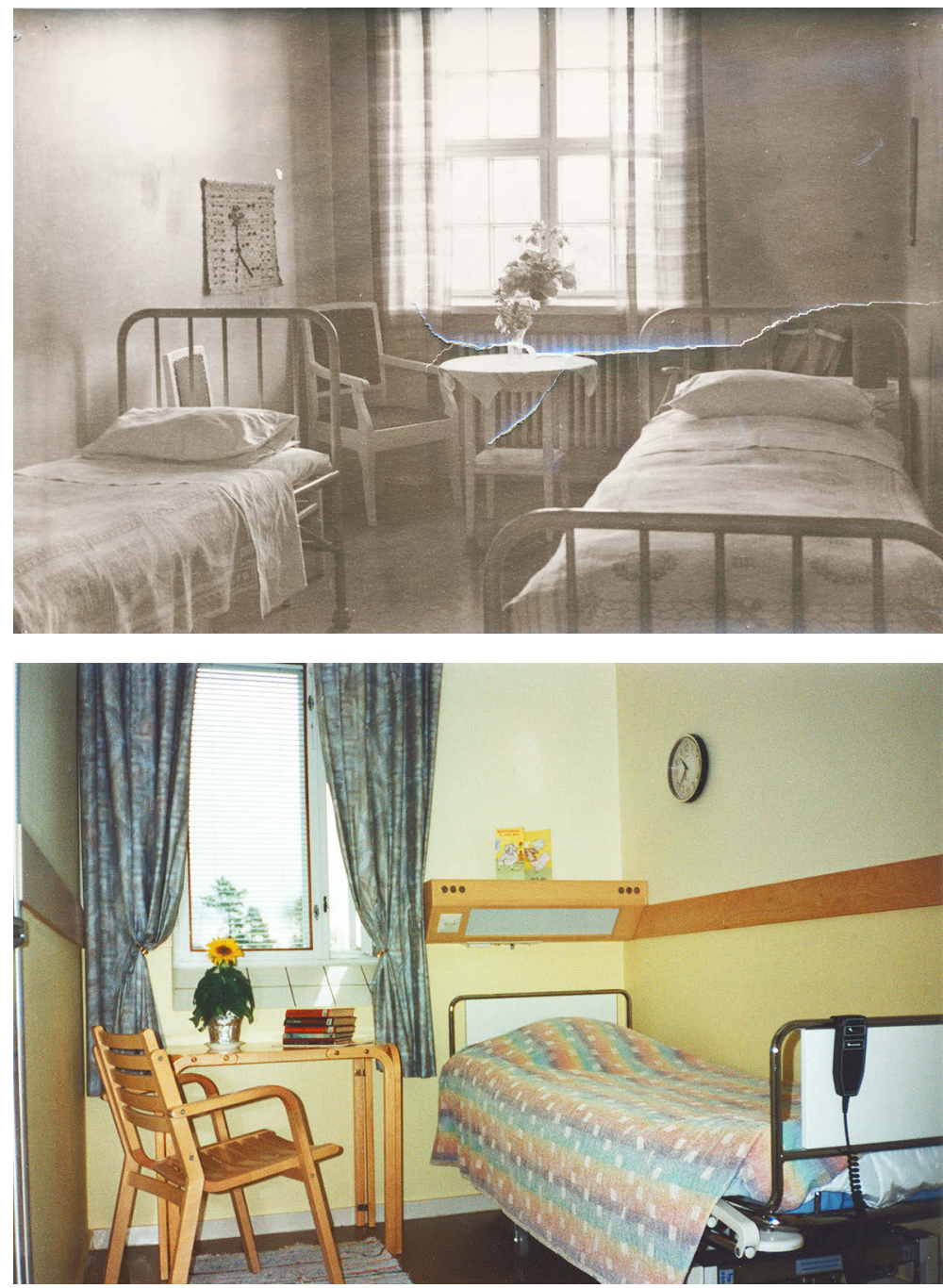

Fig. 2: Halikko hospital, (c) The Hospital District of Southwest Finland/Turku Lazaret Museum

Fig. 3: Juurikkaniemi hospital, (C) Hospital Museum of the Central Finland Health Care District 
them. In the excerpt, the writer refers to a sense of space and to the imagination, and strangely, despite its form, the memory of the corridor brought corporeality in all its dimensions vividly present alongside the frontal orientation of running through the corridor in the happening. All this affirms the corridor as a no man's land or as a state of waiting for something indeterminate, or as a passage from one state to another.

The notion of living one's memories through corporeality parallels the thought by Maurice Merleau-Ponty (2005 [1945]: xviii): “The world is not what I think but what I live through." The phenomenological approach focuses on the lived, experiencing body in the world and the value of the immediacy of experience. As the written memories demonstrate, the intertwining of the human being and the environment and patients' sensitivity to materialities is intense in mental hospitals. When moving to the spoken excerpt above, the process of attuning to the image of the corridor as if it were really there induces thinking-in-action that transcends rational thinking.

\title{
Patients' Rooms
}

\begin{abstract}
My mother's room was tiny, white, and sparsely furnished. There was a narrow bed, a chair and a table, and perhaps a few extra chairs for visitors. ... I was mentally prepared for her to scream and cry and be upset, however she was frighteningly calm, and as expressionless and pale as the hospital building itself. ${ }^{7}$ (SKS 0339, relative)
\end{abstract}

Sari:

While two photographs of patients' rooms feature shared objects like beds, chairs, and tables, they also show interesting differences that remind us of the historicity of buildings and their interiors. The first picture shows Halikko hospital. The hospital was built, along with many other mental hospitals in Finland, around the beginning of the twentieth century. Many of these buildings, which greatly resemble each other, were designed by Axel Mörne (1886-1935). The rooms have high ceilings, high windows, long, wide corridors, and interiors dominated by the color white. The old photograph of Halikko hospital is slightly torn, a feature which incorporates new historical layers into the hospital's environment. 
White was typically used in the interiors of hospitals and in the interiors of other public buildings. For example, as described by Mohsen Mostafavi and David Leatherbarrow (1993), whiteness in the architecture of Le Corbusier (I887-I965) was not only understood to signify honesty, dependability, objectivity, and "truth," but it also aimed to transcend class barriers (Mostafavi/Leatherbarrow 1993: 73-77). It has also been debated whether white should be understood as a color or not (e.g. Kandinsky I9I2; Oettl 2008). Wassily Kandinsky (I866-I944), reflecting on the spiritual influences of colors, describes white as a great silence. That silence is not dead, but pregnant with possibilities like pauses in music that temporarily break the melody (Kandinsky I977 [I9I2]: 39).

The color white was frequently mentioned in the writers' memories of mental hospitals. White was described as present in the clothing of personnel, in corridors, on walls and window sills, in the snow outside, and even in the faces of patients. Mental hospitals can be understood as liminal spaces, where all possibilities are open and movements toward better and worse are equally possible. The white interiors of hospitals emphasize the idea of openness. In our research material, the whiteness of hospital interiors has sometimes aroused wonder and even dislike in patients and visitors, particularly when they have entered hospital buildings after first passing through their beautiful and blooming gardens.

Over the decades, Finnish hospital wards have been furnished in various ways. At the beginning of the twentieth century, patients' bedsteads were usually made of iron. Windows were hung with long curtains in light fabrics and patients' rooms contained small tables and chairs and indoor plants, as can be seen in the photograph of a patient's room in Halikko hospital (fig. 2) (cf. e.g. Neuman-Rahn 1924: 255, 348-349). The number of beds varied across hospitals and wards. Positive experiences of hospital environments in our research data usually relate to the older hospital environments dating from the beginning of the twentieth century. These were usually located outside cities and towns and surrounded by gardens, lakes, and forests (cf. e.g. Ahola 20I5: 30-3I).

Around the middle of the twentieth century a great many new mental hospitals, socalled B-hospitals, were built in Finland. These hospitals were mainly designed for chronic patients, and the buildings were typically low, compact blocks (ibid.: 47-57). They were also furnished in new styles. At the end of the century, darker colors were used in hospital interiors, and natural materials, like wood, were typical design elements. The photograph taken in Juurikkaniemi hospital (fig. 3) shows how patients' rooms were furnished at the end of the twentieth century. 
Thus, mental hospitals exhibit interesting cultural and historical layers. Spaces affect patients, and the personal history of patients is mingled with the history of the buildings they occupy. Memories of other public buildings also intertwine with experiences of mental hospitals. People's images of mental hospitals and other public buildings are combinations of the real and imagined - constructions combining cultural imagery, narratives, and personal memories.

Kirsi:

In various performance sites, I was attracted by the corners, as these emphasized the tininess and gloominess of a room. The furniture described in the excerpt and in the photograph made my movements cautious as if I were too large, as if moving around in a playhouse. The corporeal connection to the paleness or whiteness became obvious and strong. When touching the wall with my hands, arms, legs, sides, back, and cheek, as well as being touched by it, the porousness and transparency of the corporeal experience invited me to disappear into the wall, to become the wall. This led to a slowing of movements, at once vertical and yet still moving. Also, while moving, the surrounding gloominess became like a thin, white material that passes through everything. That something, a transparent web-like whiteness, permeated my skin touching the curves of my bones. It fascinates yet it escapes - a brief lived encounter. The notion of tininess and whiteness also brought a sense of security and simplicity: no need to make big movements, and it supported me in letting go of some features of the known I.

The wall and furniture are seen here as inherently vital; they are moving companions that induce one to act differently, pushing aside one's own will and control. Jane Bennett (20I0: xiii, I22) discusses vital materiality in the same manner, laying the foundation for a materiality that is far from being passive or mechanistic, and she equates affect with materiality. Encounters with vital matter reveal a wider notion of agency in materialities and question the notion of human mastery. Moreover, one's own corporeality is material, although not fully human; instead, it has an "alien" quality (ibid.). Bennett stresses "the very radical character of the fractious kinship between the human and the nonhuman" (ibid.: II2, emphasis original) through the notion of vital materiality. Writing of alien quality in encounters with materiality, Bennett questions the notion that humans have full control over their own corporeality, since it entails something that is strange, unknown, and that strangeness within materiality resembles my lived notions of materiality. 


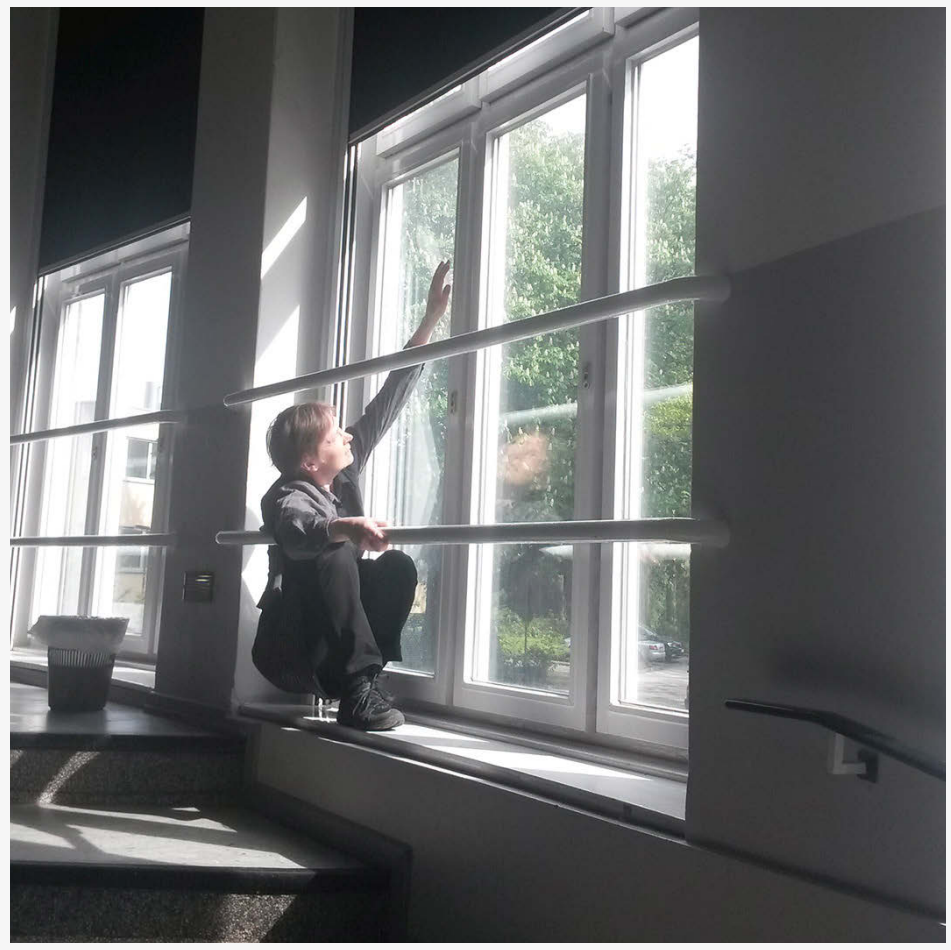

Window Sill

Each night was sleepless during the three-month treatment period. I sat on the window sill in my room. I liked that. It was painted white, a broad concrete shelf. I watched the outside world until the early hours. Watching the falling snow brought a kind of beautiful fulfilment. It calmed down the accumulation of anxiety that was circling around inside me. ${ }^{8}$ (SKS 0483, patient) 
Sari:

As stated by Edith Stein, the phenomena of life, such as growth, development, aging, health, sickness, vigor, and sluggishness, can fill the living body and soul, color every spiritual act and every bodily event. Therefore, through posture and movement we can see how a person feels and make evaluations of her mental and bodily state (Stein I989 [I9I6]: 68-69; see also Parviainen 2003: 337-338).

Sara Ahmed has reflected on how spaces, with their material dimensions, shape bodies. Edmund Husserl and Maurice Merleau-Ponty have described bodily histories as sedimented histories. Phenomenologically, bodies are understood as shaped by histories which are performed in their comportment, postures, and gestures (Ahmed 20I0: 246-250). Traditionally, the patients have lived in mental hospitals for a long time, even decades, and the materiality of hospitals has greatly affected their corporeality. As inmates, patients have spent most of their time in the hospital's rooms or corridors, and the materiality of hospitals has sedimented in their bodies.

Photographs generate rich corporeal knowledge of mental hospitals as lived spaces by opening their unique perspectives on materiality (Kuuva 20I8). How many beds were there in a room, and what possibilities for privacy did patients have? What kinds of pillows, blankets, and curtains were used? What did it feel like to walk through the hospital's corridors and up and down its staircases, and in the yards, gardens, and woods surrounding the hospital, or to be a patient looking through the window at the landscape - day after day, month after month, even year after year?

Because photographs of mental hospitals are linked with specific sites and situations, they may be reminiscent of a person's experiences of other, similar sites like general hospitals, schools, and other public buildings. The corporeal knowledge triggered by photographs resonates with images of other rooms stayed in, corridors walked, beds slept in, and clothing worn when one has been tired, hopeful, sad, anxious, or relieved. In our performative event, the resonance between texts, photographs, and movement may open a pathway for corporeal imagination and empathic experience.

Kirsi:

Corridors and windows have something in common, since they both open up further possibilities and act as bridges between different rooms or indoor and outdoor sites. On the institutional scale, a window sill can offer one a place of safety, security. A window sill is a kind of threshold at which day and night, outside and inside are both present. Snowfall brings softness, silencing sounds and rendering the land- 
scape harmonious, covering all in a white blanket. Night time strengthens the density of spatiality; others are sleeping, tranquility fills the person and environment. Something is being transferred when one pauses to watch the snowfall, something that moves through the person, window and air. Spaces, materialities and immaterialities intertwine with each other and permeate the corporeality of the experiencer, settling into her horizon of experience. Furthermore, sitting on a window sill at that moment or being moved by the excerpt recalls the description given by Sara Ahmed (2006:9): "spaces are like a second skin that unfolds in the folds of the body." And each performing site, the time of day, quality of the light, echoes of sounds, and participants influence and fold in to an ever-changing corporeality.

In performing, the writer's words about nighttime called a halt to the progression of movement, and the rhythm changed: the movement became slow, pondering, and extremely delicate. The image of snowflakes dissolved the tension in my corporeality, even the sound of my voice softened. Perceiving the landscape as dual, as two landscapes transparent and overlapping, was always a powerful experience: to see the view opening from the window at each venue, e.g. seeing tall pine trees in the light of May while at the same time seeing the landscape covered in snow as described in the excerpt. The image of snowfall in the calmness drew my attention. No need to move much, but just to rest in movement. Each change of position was enough. The movements were clearly outlined and, importantly, breathing was autonomous, unconstrained. Something consoling that made it possible for me to be at one with both environments and their atmospheres, a sense of thereness and hereness without any contradiction (Heimonen 2009).

The three examples given above suggest how movement, speech, and photographs can bring forth the responses of patients and visitors to the affective materialities of the mental hospital. Those in the audience attune to these (im)materialities, and their corporeality is in a continuous process of becoming. Corporeality does not pre-exist; instead it is co-produced relationally in specific situations and sites (McCormack 2015). In her discussion of Bruno Latour's notion of the body, Lisa Blackman, referring to the connections that produce and enact bodies, describes the body as an assemblage that is performative, as "an association and concatenation of a range of heterogeneous elements which produce what we take entities to be" (Blackman 2008: I22, emphasis original). The body is thus taken as a mixture of intertwined processes, and these relational connections denote what the body can do or become (Latour 2004; Blackman 2008: I22-123). These descriptions invite one to ponder the possibilities of patients in mental hospitals to corporeally sense 
and attune to the (affective) materialities of their situation and, at each moment, to be in a state of becoming in their various relational connections. Living in and through corporeality, memories enhance sensitivity and make us fully aware of the materialities surrounding us.

\section{Possibilities and Limitations of Corporeal Empathy}

In this article, the entanglement or intertwining of materiality and person in a mental hospital has been investigated as a corporeal attunement to written experiences, photographs, and movement. The present collaboration between two researchers has shown how corporeal empathy towards others and towards material objects can be induced by performative events that foreground the significance of (im)materiality in a mental hospital. The corridors, rooms, windows, and whiteness described in the written memories emphasize the multidimensional aspect of materiality.

The idea underlying our performative events has been to create possibilities for the awakening of corporeal empathy in the audience. We assume that corporeal empathy can be activated through multi-modal performative events. In the present instance, mental hospitals and their environments are understood as carriers of affective meanings, and written memories of environments resonate with people through corporeality. When they imagine life in a mental hospital of the past, spectators use their own corporeal memories of institutions like hospitals and schools. Thus, both performers and spectators are simultaneously present in different spaces, while the past flows through them and assimilates with the present.

The questions of singularity and situationality are important in this research. Each memory is unique, as are our readings of them: environments and one's own corporeality with its traditions and notions leave their imprint. Moreover, each spectator or participant in a performative event has a unique relation to it, which, via one's own corporeality and openness to the specific situation, enhances and guides the possibilities for corporeal empathy.

In the context of a performative event, people find themselves in a situation in which they have diminished control. They may even be exposed to something that is not pleasurable or triggers unpleasant memories. How far should people be protected from this and for what reasons? The most important objective has been to offer audiences the opportunity to engage in others' memories, yet at each per- 
formative event the ethical questions remain of how far one can go while leaving intact the integrity of the writers of the original memories and not insulting them.

The aim of our method is not to indulge in our personal issues; on the contrary, it is to step beyond our subjectivity by taking a different approach to the research material that involves trusting one's own corporeal experience. This does not mean offering an interpretation that all can agree on, or suppressing subjectivity, or neglecting the cultural traditions and historicity of each corporeality. However, the method may reveal something about memories of lived materiality that is uncommunicable by other means.

We suggest that this collaborative method may also be useful to other researchers studying past experiences. The method encourages researchers to listen to the resonance of words, pictures, and movement, and to their own corporeality. We stress the importance of thinking, reading and interpreting one's corporeality, and valuing the knowledge it brings while acknowledging its ever-changing modes and situational aspects. This method offers a space for the unsayable that dwells in photographs and in corporeality, and thus it offers an alternative interpretation for lived memories.

\title{
Epilogue
}

\author{
And the end of all our exploring \\ Will be to arrive where we started \\ And know the place for the first time \\ T.S. Eliot (1943)
}

This study, after starting at and travelling through a corridor, has sought to demonstrate the power and influence of (im)materialites and material objects in encounters with humans. Lived experiences in mental hospitals have been transformed into performative events and then into writing (this article) in order to take the co-existence between humans and materiality into account. The article invites the reader to pay attention to the material environment, and how one is - even if unconsciously - continuously encountering it, and how it affects one's actions and decisions. 


\section{Notes}

\section{1}

This article stems from our conference presentation in Hamburg in 2018, in which we opened up some insights of selected memories through a performative event: Sari was reading memories and showing some photographs while Kirsi was moving them. This event encouraged us to reconsider our different approaches and propose a way in which they could be interwoven while maintaining the integrity of both of them.

2

The research project is funded by Kone Foundation, 2017-2020, https://muistoihinkaivertuneet. wordpress.com/english/.

\section{3}

Kinesthetic empathy and choreographing empathy, which are understood as sub-concepts of corporeal empathy, are also included in our approach. In the context of dance, kinesthetic empathy is closely tied to movement - in particular to the movement between humans. Choreographing empathy, in turn, denotes the construction of a kind of physicality, which guides the kinesthetic experience in the context of dance. It refers to the particular means of creating a dance performance by choreographers focusing on kinesthetic empathy which is reflected to the audience (e.g. Foster 2011; Heimonen 2009; Parviainen 2002; Jones 2012). We assume that the relationship between human beings and their material environment can be discussed more comprehensively through corporeal empathy than through kinesthetic and choreographing empathy.

\section{4}

Cf. "About Skinner Releasing Technique," http://www.skinnerreleasing.com/aboutsrt.html.

\section{5}

"Joillain osastolla kiinnitin huomiota leveisiin käytäviin jotka antoivat tilan tuntua niillä kävellessä ... ja se antoi mielikuvitukselle kyytiä" (SKS 0395). All quotations originally in Finnish were translated by Kirsi Heimonen.

\section{6}

"Jeg tenker at det er en bygding med sjel. Det har vaert mange gode sjeler som har vandret her, som har avsluttet livet sitt. Jeg synes liksom det er fred over hele huset. Det er nog godt med huset. Det er sjel i hvert rom" (Larsen 2008: 4).

\section{7}

"Äitini huone oli pieni, valkoinen ja niukasti kalustettu. Siellä oli kapea sänky, tuoli ja pöytä, ehkä pari ylimääräistä tuolia vieraille. ... Olin henkisesti varautunut siihen, että äitini huutaisi ja itkisi ja olisi pois tolaltaan, mutta äitini olikin pelottavan tyyni, yhtä eleetön ja väritön kuin sairaalarakennus itsessään" (SKS 0339).

\section{8}

"Kolmen kuukauden hoitojakson aikana jokainen yö oli uneton. Istuin huoneessani ikkunalaudalla, pidin siitä; se oli valkoiseksi maalattu, leveä betoninen syvennys ikkunan äärellä. Katselin myöhään aamuyöhön asti ulkomaailmaa. Lumisateen katseleminen toi jotain kaunista tyydytystä, rauhoitti sisimmässäni kiertävää ahdistuksen keskittymää" (SKS 0483). 


\section{Bibliography}

Aaltola, Elisa/Keto, Sami (2017): Empatia. Myötäelämisen tiede [Empathy. Science of compassion], Helsinki: Into.

"About Skinner Releasing Technique," January 3, 2019, http://www.skinnerreleasing.com/aboutsrt. html, accessed February 12, 2020.

Ahmed, Sara (2010): "Orientations matter." In: Coole, Diana/Frost, Samantha (eds.): New Materialisms: Ontology, Agency, and Politics, Durham/ London: Duke University Press, pp. 234-257.

Ahmed, Sara (2006): Queer Phenomenology: Orientations, Objects, Others, Durham/London: Duke University Press.

Ahola, Teija (2015): Terveyttä kaikille: B-mielisairaalat 1950-luvulta 1970-luvulle [Health for all: B mental hospitals from the 1950's to the 1970's], https://www.museovirasto.fi/uploads/Arkisto-jakokoelmapalvelut/Julkaisut/b-mielisairaalat.pdf, accessed February 12, 2020.

Bennett, Jane (2010): Vibrant Matter: A Political Ecology of Things, Durham/London: Duke University Press.

Blackman, Lisa (2008): The Body: The Key Concepts, Oxford/New York: Berg

Coole, Diana/Frost, Samantha (eds.) (2010): New Materialisms: Ontology, Agency, and Politics, Durham/London: Duke University Press.

Eliot, T.S. (1963): Collected Poems 190o-1962, London: Faber and Faber Limited.

Foster, Susan Leigh (2011): Choreographing Empathy: Kinesthesia in Performance, London/ New York: Routledge.

Gibson, James J. (1979): The Ecological Approach to Visual Perception, Boston: Houghton Mifflin.

Heimonen, Kirsi (2009): Sukellus liikkeeseen: Liikeimprovisaatio tanssimisen ja kirjoittamisen lähteenä [Dive into Movement: Movement Improvisation as a Fountain of Dancing and Writing], Acta Scenica 24, Helsinki: Teatterikorkeakoulu. Jones, Amelia (2012): "Kinesthetic empathy in philosophical and art history: Thoughts on now and what art means." In: Reynolds, Dee/Reason, Matthew (eds.): Kinesthetic Empathy in Creative and Cultural Practices, Bristo//Chicago: Intellect, pp. 11-15. Kandinsky, Wassily (1977 [1912]): Concerning the Spiritual in Art, transl. M. T. H. Sadler, New York: Dover.

Kuuva, Sari (2018): "Ruumiillinen tieto sairaalaympäristöissä: Valokuvia suomalaisista mielisairaalahistoriikeista" ["Corporeal Knowledge in the Environments of Hospitals: Photographs from Finnish Histories of Mental Hospitals"]. In: Ennen ja nyt. Historian tietosanomat 4/2018, http://www.ennenjanyt net/2018/12/ruumillinen-tieto-sairaalaymparistoissa -valokuvia-suomalaisista-mielisairaalahistoriikeista, accessed February 12, 2020.

Larsen, Inger Beate (2008): "Det sitter i veggene": Materialitet og mennesker i distriktpsykiatriske sentra ["It's Embedded in the Walls": Materiality and people in district psychiatric centres], dissertation, Bergen: Universitetet i Bergen.

Latour, Bruno (2005): Reassembling the Social: An Introduction to Actor-Network Theory, Oxford: Oxford University Press.

Latour, Bruno (2004): "How to Talk About the Body? The Normative Dimensions of Science Studies." In: Body \& Society 10/2-3, pp. 205-30.

Lipps, Theodor (1960 [1903]): "Empathy, Inner Imitation, and Sense Feelings." In: Rader, Melvin (ed.)

A Modern Book of Esthetics: An Anthology, 3rd edition, New York: Hold, Rinehart and Winston, pp. 374-382.

Maibom, Heidi L. (2017): "Introduction to Philosophy of Empathy." In: Maibom, Heidi L. (ed.): Routledge Handbook of Philosophy of Empathy, London/New York: Routledge, pp. 1-9. Mostafavi, Mohsen/Leatherbarrow, David (1993): On Weathering: The Life of Buildings in Time, Boston, Mass: MIT Press.

McCormack, Derek P. (2015): "Atmospheric Choreographies and Air-Conditioned Bodies." In: Hunter Victoria (ed.): Moving Sites: Investigating Site Specific Dance Performance, London/New York: Routledge, pp. 79-92.

McCormack, Derek P. (2013): Refrains for Moving Bodies, Durham/London: Duke University Press. 
Merleau-Ponty, Maurice (2005 [1945]): Phenom-

enology of Perception, transl. Colin Smith, London/New York: Routledge.

Nancy, Jean-Luc (2007 [2002]): Listening, transl. Charlotte Mandell, New York: Fordham University Press.

Neuman-Rahn, Karin (1924): Sielullisesti sairas ihminen ja hänen hoitonsa [A mentally ill person and his care], Porvoo: WSOY.

Oettl, Barbara (2008): Weiss in der Kunst des 20. Jahrhunderts: Studien zur Kulturgeschichte einer Farbe, Regensburg: Schnell \& Steiner.

Parviainen, Jaana (2002): "Kinesteettinen empatia: Pohdintoja Edith Steinin empatiakäsityksen ulottuvuuksista" ["Kinesthetic Empathy. Reflections on the Dimensions of Edith Stein's Conception of Empathy."] In: Haaparanta, Leila/Oesh, Erna (eds.): Kokemus [Experience], Tampere: Tampereen yliopistopaino, pp. 325-348.

Stein, Edith (1989 [1916]): On the Problem of Empathy, 3rd revised edition, transl. Waltraud Stein, Washington, D. C.: ICS. Publications. 